\title{
Dike-fault interaction during the 2004 Dallol intrusion at the northern edge of the Erta Ale Ridge (Afar, Ethiopia)
}

\author{
Adriano Nobile, ${ }^{1,2}$ Carolina Pagli, ${ }^{2}$ Derek Keir, ${ }^{3}$ Tim J. Wright, ${ }^{2}$ Atalay Ayele, ${ }^{4}$ \\ Joel Ruch, ${ }^{1}$ and Valerio Acocella ${ }^{1}$ \\ Received 17 July 2012; revised 29 August 2012; accepted 4 September 2012; published 12 October 2012.
}

[1] During continental rifting the interaction between faulting and magmatic intrusions is not well understood. Using InSAR and seismicity, we show that a $\sim 0.06 \mathrm{~km}^{3}$ dike was intruded along the Dallol segment, Ethiopia and was accompanied by a $\mathrm{M}_{\mathrm{w}} 5.5$ earthquake and associated fault slip along the western flank of the rift. The intrusion was fed by a previously unidentified magma chamber under Dallol. The total seismic moment release was $\sim 2.3 \times 10^{17} \mathrm{Nm}$, $\sim 10 \%$ of the geodetic moment. This is a higher proportion than during the 2005-2009 Dabbahu rifting episode, which ranged between $1-4 \%$ of the geodetic moment. A larger component of faulting occurs at Dallol than at Dabbahu segment, a feature we interpret to be related to the proximity $(10 \mathrm{~km})$ of the Dallol segment to the rift margin, where welldeveloped faults facilitate slip. Citation: Nobile, A., C. Pagli, D. Keir, T. J. Wright, A. Ayele, J. Ruch, and V. Acocella (2012), Dike-fault interaction during the 2004 Dallol intrusion at the northern edge of the Erta Ale Ridge (Afar, Ethiopia), Geophys. Res. Lett., 39, L19305, doi:10.1029/2012GL053152.

\section{Introduction}

[2] The Afar Depression is an area of incipient seafloor spreading at the intersection between the southern Red Sea, the Gulf of Aden and the Main Ethiopian rifts [Hayward and Ebinger, 1996; Beyene and Abdelsalam, 2005]. Rifting in Afar commenced at $\sim 30$ Ma with extension initially accommodated on the large offset border faults [Wolfenden et al., 2004]. Since then, strain has also localized in-rift to 60-100 km long, 10-20 km wide axial fissured volcanic segments, including the Erta Ale Ridge (EAR), northernmost Afar [Barberi and Varet, 1970; Hayward and Ebinger, 1996]. Current spreading rates along Afar vary from $\sim 7 \mathrm{~mm} / \mathrm{yr}$ at the northern edge to $\sim 20 \mathrm{~mm} / \mathrm{yr}$ further south at the Dabbahu segment [McClusky et al., 2010].

[3] The Dallol rift segment is located at the northernmost end of EAR (Figure 1a), where crustal thickness is $14 \mathrm{~km}$ [Makris and Ginzburg, 1987]. Recent magmatic activity in the EAR includes subsidence of Gada-Ale volcano and

\footnotetext{
${ }^{1}$ Dipartimento di Scienze Geologiche, Università degli Studi "Roma Tre," Rome, Italy.

${ }^{2}$ School of Earth and Environment, University of Leeds, Leeds, UK.

${ }^{3}$ National Oceanography Centre Southampton, University of Southampton, Southampton, UK.

${ }^{4}$ Institute of Geophysics, Space Science and Astronomy, Addis Ababa University, Addis Ababa, Ethiopia.

Corresponding author: A. Nobile, Dipartimento di Scienze Geologiche, Università degli Studi "Roma Tre," Largo San Leonardo Murialdo, 1, I-00146 Rome, Italy. (anobile@uniroma3.it)

(C)2012. American Geophysical Union. All Rights Reserved. 0094-8276/12/2012GL053152
}

faulting caused by magma withdrawal between 1993 and 1996 [Amelung et al., 2000], an eruption of the Alu-Dalafilla volcano in 2008 [Pagli et al., 2012] and an overflow event of the Erta Ale lava lake in 2010 [Field et al., 2012b]. The EAR is commonly reported to include six active volcanoes, spaced at $\sim 10 \mathrm{~km}$ intervals in the NNW-SSE direction [Barberi and Varet, 1970], but here we have identified a $2.4 \mathrm{~km}$ deep active magma reservoir beneath Dallol that likely fed a dike intrusion in 2004 and we suggest that a seventh magmatic center should be added.

[4] Due to the remoteness of the area, few direct observations of Dallol have been made and volcanic products have not been found. The only major reported activity has been the creation of a $30 \mathrm{~m}$ diameter crater during a phreatic eruption in 1926 [Siebert et al., 2010]. The Dallol rift segment is a depressed area $\sim 120 \mathrm{~m}$ below sea level, it includes a 40-50 m high (above the surrounding plane) and $\sim 2 \mathrm{~km}$ wide mound (which here will be referred to as the Dallol magmatic center), and an active hydrothermal field [Carniel et al., 2010]. Salt deposits cover a $\sim 50 \mathrm{~km}$ long and $\sim 10 \mathrm{~km}$ wide area, consistent with the region being covered by the sea until at least $\sim 32000$ years ago [Bonatti et al., 1971; Carniel et al., 2010].

[5] A previous seismic swarm of hundreds of earthquakes was reported north of Dallol between April and May 1993 (Figure 1b) [Ogubazghi et al., 2004]. The largest $\mathrm{M}_{\mathrm{w}} 5.2$ earthquake has a normal faulting plane solution along a NNW striking plane, in agreement with the strike of surface fractures observed during field investigations [Ghebreab and Solomon, 1994].

[6] An along-axis dike intrusion occurred in the Dallol segment in October 2004. In this paper, we use InSAR and seismicity to place fundamental constraints on the interaction between diking and faulting in a region at the final stages of continental breakup. Our data suggest that a shallow active magma chamber exists below Dallol which deflated in response to along rift dike intrusion. Furthermore, three subsequent SAR acquisitions allow us to detect temporal changes in deformation from the early and late phases of the intrusion. Comparisons of our results to rifting episodes observed elsewhere highlight different mechanisms in styles of rifting.

\section{Data}

[7] We processed a time series of SAR images acquired by ENVISAT satellite in ascending and descending orbits over the Dallol region using the JPL/Caltech ROI_PAC software [Rosen et al., 2004]. The interferograms span different time periods from 2003 and 2010, enabling us to distinguish between co- (Figure 2), pre-, and post-diking phases 


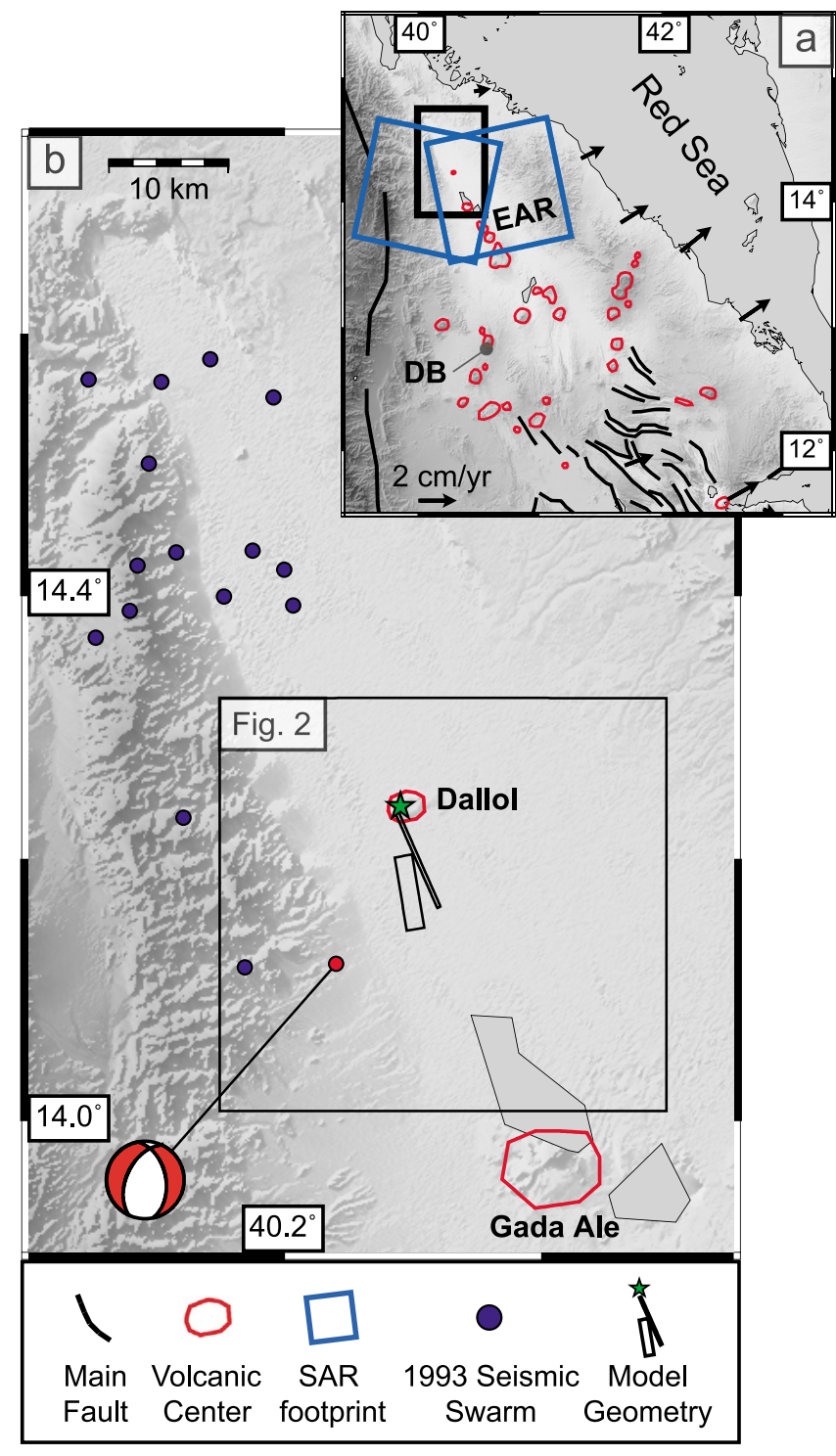

Figure 1. (a) Map of northern Afar and (b) study area. The black box in (a) gives the location of the area shown in (b). In (a) and (b) red outlines mark volcanic centers location. In (a) arrows are GPS velocities by McClusky et al. [2010]. Blue rectangles mark the Envisat Track 321 and 28 footprint with $\mathrm{EAR}=$ Erta Ale Ridge and $\mathrm{DB}=$ Dabbahu. In (b) red filled circle marks $2004 \mathrm{M}_{\mathrm{w}} 5.5$ earthquake epicenter with the focal mechanism from Craig et al. [2011]. Blue filled circles are 1993 seismic swarm epicenters [Ogubazghi et al., 2004]. Green filled star is the Mogi source, the black thick line marks the dike and the black rectangle the fault.

(Figure $\mathrm{S} 1$ in the auxiliary material). ${ }^{1}$ In particular, an acquisition on 27 October 2004 allows us to observe two different phases during dike intrusion (Figure $2 \mathrm{~g}$ ).

[8] A descending interferogram spanning from 22 September to 01 December 2004 shows a deformation pattern consistent with a dike intrusion, with up to $\sim 30 \mathrm{~cm}$ of range increase over a $9 \mathrm{~km}$ long, NNW-SSE trending area along

${ }^{1}$ Auxiliary materials are available in the HTML. doi:10.1029/ 2012GL053152. the rift axis south of Dallol (Figure 2a). The signal also includes a main side lobe of range decrease on the eastern flank, while another lobe of range increase is only partially visible on the western flank, due to loss of coherence. A roughly circular area of range increase of $\sim 12 \mathrm{~cm}$ is also observed at the Dallol magmatic center, consistent with subsidence. An ascending interferogram spanning from 28 July 2004 to 19 April 2006 shows a pattern of range increase on the western flank of the rift axis, but it is incoherent in the other areas (Figure 2d).

[9] An additional descending interferogram spans the later period of the intrusion, from 27 October to 01 December 2004 (Figure 2g). Smaller magnitude of deformation occurred along the axis of the rift segment and at the Dallol magmatic center ( $\sim 5 \mathrm{~cm}$ of range increase), indicating that most of the intrusion and the subsidence occurred before 27 October 2004 but some deformation continued between 27 October to 01 December.

[10] Pre- and post- intrusive interferograms show no significant deformation in Dallol from 28 November 2003 to 22 September 2004 and from 16 March 2005 and 24 May 2006 (Figure S1).

[11] Primary constraints on the seismic activity associated with the deformation are provided by the ISC earthquake catalog, which reports earthquakes with $\mathrm{M}_{\mathrm{w}} 5.5$ on 22 October at 12:00, $\mathrm{M}_{\mathrm{b}} 4.1$ at 12:30 UTC, and $\mathrm{M}_{\mathrm{b}} 4.1$ on 4 November at 01:05 UTC. Since dike intrusion is commonly associated with intense but low magnitude seismicity near the dike edge [e.g., Roman and Cashman, 2006], we examined earthquakes on continuous seismic data recorded at FURI, near Addis Ababa, $\sim 600 \mathrm{~km}$ away from Dallol, to better understand the timing of the dike intrusion and large earthquakes (auxiliary material). This shows that the activity started with a burst of low magnitude $\left(\mathrm{M}_{\mathrm{L}} 2-3\right)$ earthquakes during 08:12-09:40 (Figure S2a), followed by quiescence until the $\mathrm{M}_{\mathrm{w}} 5.5$ earthquake at 12:00 and $\mathrm{M}_{\mathrm{b}} 4.1$ shortly afterwards at 12:30 (Figure S2b). This suggests that the $M_{w} 5.5$ earthquake was induced by an earlier phase of dike intrusion. Several earthquakes were recorded thereafter until 24 October (Figure 3a), consistent with the intrusion continuing after the $\mathrm{M}_{\mathrm{w}} 5.5$ earthquake. The majority of the seismicity occurred before 27 October (Figure 3a), but additional bursts of low magnitude earthquakes followed between 29-31 October and on 4 November, also consistent with InSAR observations suggesting intrusion during these time periods.

\section{Modeling}

[12] We inverted jointly the descending and ascending interferograms (Figures $2 \mathrm{a}$ and $2 \mathrm{~d}$ ), considering a subvertical $\sim \mathrm{NW}$-SE trending dike south of Dallol, a deflating Mogi source below the Dallol magmatic center and a normal fault on the Western side of the dike, buried in an homogeneous, elastic half space with a Poisson's ratio of 0.25 . Before the inversion, the number of data points was subsampled using a quadtree algorithm [Jónsson et al., 2002]. In order to find the best-fit model parameters we followed a two-step approach. We started by using a non-linear inversion, consisting of simulated annealing optimization technique, followed by a derivative based method [Cervelli et al., 2002]. Uncertainties on the model parameters are calculated using a Monte-Carlo simulation, in which correlated noise is 


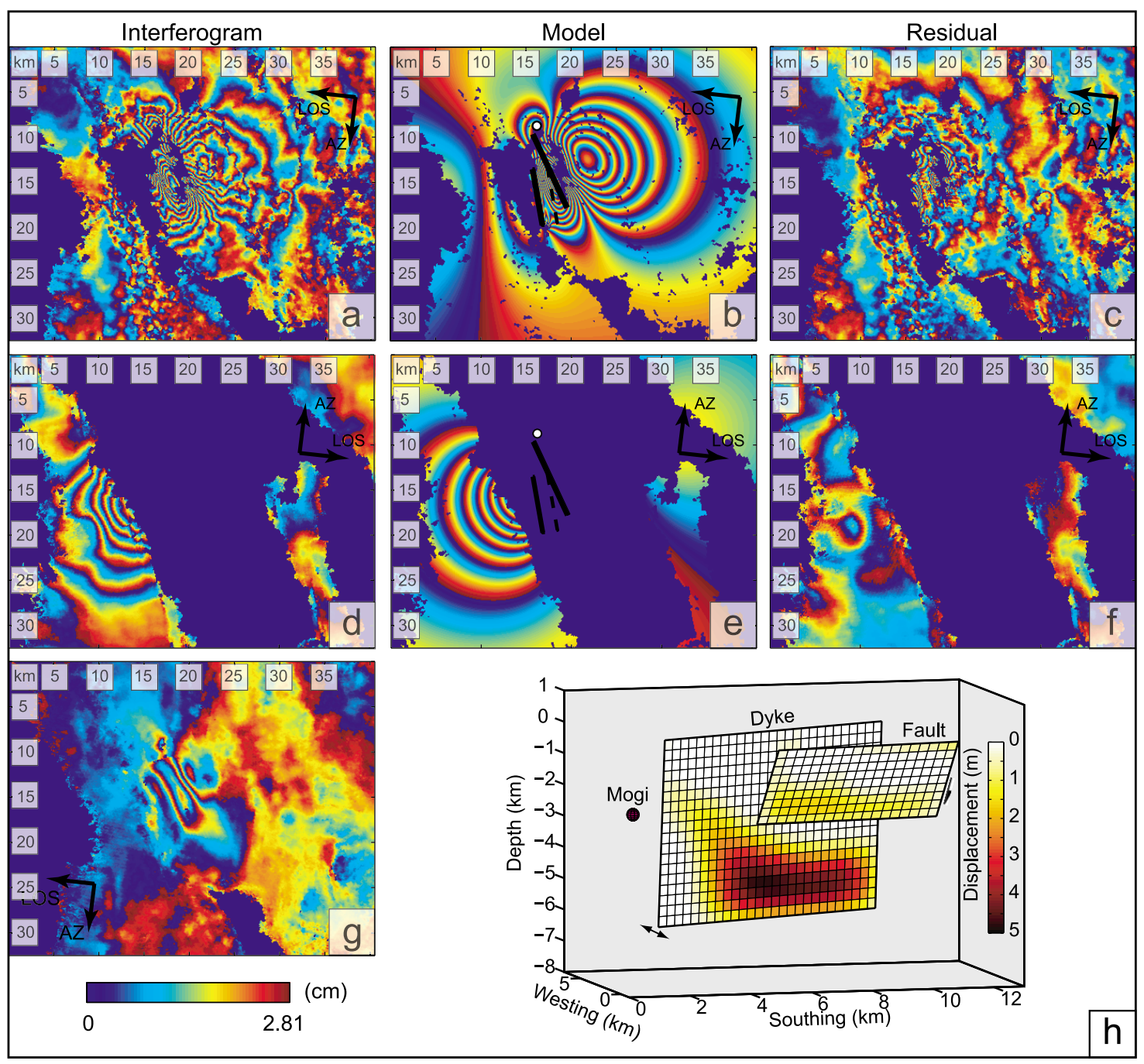

Figure 2. Best-fit model assuming a Mogi source, a dike and a fault. (a) Observed descending interferogram, between 22/09/04-01/12/04. (b) Modelled interferogram. (c) Residual. (d) Observed ascending interferogram between 28/07/0419/04/06. (e) Modelled interferogram. (f) residual. In Figures $2 b$ and 2e the white filled circle marks the Mogi source, the long thick black line is the upper edge of the dike, the short thick black line is the upper edge of the normal fault and its lower edge is marked with a dashed black line. (g) Observed descending interferogram, between 27/10/04-01/ 12/04. (h) Best-fit model geometry from joint inversion of the interferograms in Figures 2a and 2d. The colourbar below Figures $2 \mathrm{~g}$ applies to all interferograms.

added to the data [Wright et al., 2003] to obtain 100 MonteCarlo samples of the observations, which are inverted using the non-linear inversion. Then to improve the fit of the model, we fixed the geometry from the non-linear inversion model and we used a linear least-squares method to obtain variable opening and slip on the dike and fault planes that were divided into patches of $333 \mathrm{~m} \times 333 \mathrm{~m}$ area [Wright et al., 2006; Hamling et al., 2009]. We used a Laplacian smoothing operator that minimizes the trade-off between solution roughness (defined as the mean absolute Laplacian of the slip/opening model) and rms misfit (Figure S6) [Wright et al., 2003].

[13] Modeling results from the non-linear inversion show that the depth of the Mogi source is shallow, with a $90 \%$ confidence interval between $1.5-3.3 \mathrm{~km}$ of depth. The dike location and opening and the depth to its top are well constrained (Figure S5), whereas larger uncertainties are found for the dike length, with $90 \%$ confidence interval between $4.8-8.3 \mathrm{~km}$, and width, with $90 \%$ confidence interval between $2.5-8 \mathrm{~km}$. The fault model parameters are less well constrained than the Mogi source and dike (Figure S3), probably due to the limited coherence in the vicinity of the fault. Seismicity could not be used to constrain the depth of the fault due to the large uncertainties in the earthquakes depth estimates. We decided not to allow the fault to extend deeper than $3 \mathrm{~km}$, as expected in dike-induced faulting processes. Using the model geometry from the non-linear inversion we applied a linear least-squares inversion to obtain variable opening and slip on the dyke and fault (Figure 2). Our best-fit model consists of a $9 \mathrm{~km}$ long dike, extending from $\sim 2 \mathrm{~km}$ to $6 \mathrm{~km}$ depth, striking $\mathrm{N} 155^{\circ} \mathrm{W}$ and dipping $87^{\circ}$ with an intruded volume of $0.058 \mathrm{~km}^{3}$, and a $\sim 6 \mathrm{~km}$ long, normal fault striking $\mathrm{N} 170^{\circ} \mathrm{W}$ and dipping $58^{\circ}$. The model also includes a $2.4 \mathrm{~km}$ deep Mogi source under 


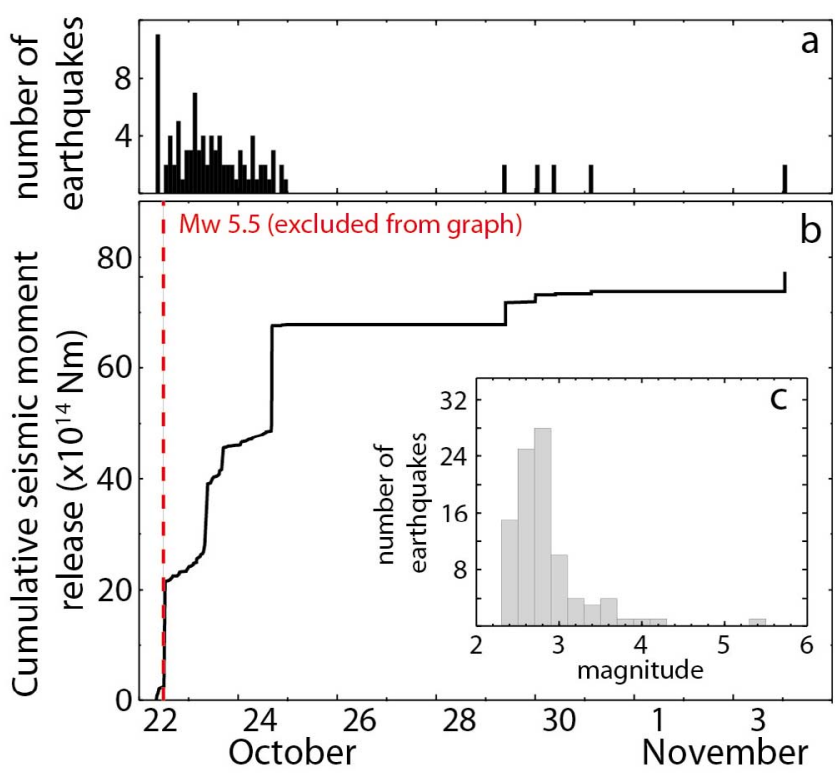

Figure 3. (a) Number of earthquake registered at FURI station between October 22 and November 4 2004. (b) Cumulative seismic moment release, we excluded the $\mathrm{M}_{\mathrm{w}} 5.5$ earthquake because is out of range. The total seismic moment release is $2.2810^{17} \mathrm{Nm}$ and the seismic moment release due to the main shock is $2.210^{17} \mathrm{Nm}$. (c) Earthquake magnitudes frequency.

the Dallol magmatic center, experiencing a volume decrease of $1.8 \times 10^{-3} \mathrm{~km}^{3}$. The model gives a total RMS misfit of $2.3 \mathrm{~cm}$ which explains $\sim 95 \%$ of the data variance. The depth of the dike $(\sim 6 \mathrm{~km})$ is in good agreement with estimates of $5 \pm 2 \mathrm{~km}$ effective elastic plate thickness in the area [Hayward and Ebinger, 1996]. Our best-fit fault model corresponds to an earthquake $M_{w} 5.6$, in good agreement with the seismically recorded $\mathrm{M}_{\mathrm{w}}$ 5.5. Models without faulting on the western side of the dike were attempted, but provided a worse fit to the data, a total RMS misfit of $4.1 \mathrm{~cm}$ ( $\sim 85 \%$ of the data variance) and required a much larger component of distributed dike opening, of up to $11 \mathrm{~m}$ (Figure S4). Furthermore, the occurrence of a $\mathrm{M}_{\mathrm{w}} 5.5$ earthquake suggests faulting.

[14] We used the same inversion approach to model an interferogram covering the later phase of the intrusion (Figure S5), from 27 October to 01 December. We find that $\sim 13 \%$ of the total dike volume was intruded during this later phase and that most opening occurred in the northern portion of the dike, closer to the Dallol magma chamber. The model also includes faulting, corresponding to a $M_{w} 5.0$ earthquake. This is in broad agreement with the seismicity, showing that a few earthquakes, up to $\mathrm{M}_{\mathrm{b}} 4.1$, occurred between 27 October-4 November (Figure 3).

\section{Discussion and Conclusions}

[15] Using InSAR and seismicity we were able to identify shallow magma movements in the Dallol rift segment in northernmost Afar. An along-rift dike intrusion occurred in 2004, triggering a $M_{w} 5.5$ earthquake on the faults at the western flank of the rift. The co-intrusive deflation of the
Dallol magmatic center suggests that the intrusion originated from a $\sim 2.4 \mathrm{~km}$ deep magma chamber, the presence of which was previously unidentified, given the lack of volcanism at the surface. The magmatic system of Dallol is probably still developing in a proto-volcanic stage, with an extrusive/intrusive ratio of zero [e.g., Gudmundsson, 1995]. Our interpretation of an active magmatic center in Dallol may also explain the 1993 swarm of earthquakes and ground fissuring, an event that bears marked similarities in characteristics of seismicity and ground deformation to other rift related intrusions such as described here in Dallol during 2004 (Figure 1b) [Ogubazghi et al., 2004]. The Dallol center may therefore be a segment centered magma chamber from which lateral intrusions are fed both to the NNW and SSE, into the upper crust of the rift axis, a magma plumbing and distribution system similar to that observed at ocean ridges [e.g., Einarsson and Brandsdóttir, 1980; Wright et al., 2012].

[16] The evolution of dike emplacement (Figure S5) indicates that the full dike length and up to $87 \%$ of the total dike volume were reached during the early phase of the intrusion between 22 and 27 October. In the later phase, between 27 October and 4 November, the remaining $13 \%$ of the dike volume was intruded, mainly in the area close to the magma chamber. This pattern is consistent with observations from some of the dikes intruded during the Dabbahu rifting episode, where dike induced seismicity initially migrates from the magma source to the distal dike tip, and then later migrates backward towards the source [e.g., Keir et al., 2009; Belachew et al., 2011]. A possible explanation is that the overpressure in the magma chamber that drove the dike intrusion decreased with time causing the magma to reach further away in the early phase.

[17] Discrepancies between dike volume and volume change of the magma chamber are commonly observed during magma transfers and have been explained by the compressibility of the magma and different compliance of dike and magma chamber [Rivalta, 2010]. When magma migrates from the chamber into the dike, the gas-rich magma residing in the chamber expands, accommodating some of the volume change due to magma transfer [Johnson, 1992; Johnson et al., 2000; Rivalta and Segall, 2008]. Volume changes of the magma chamber only $20 \%-40 \%$ of the total volume of magma injected in a dike have been reported, e.g., during the 2005 intrusion at Dabbahu [Wright et al., 2006]. For the 2004 Dallol intrusion, the volume decrease of the Mogi source was just $\sim 3 \%$ of the dike volume, less than commonly observed. One explanation is that our estimate of the volume change of the Mogi source is somewhat small, since some residual subsidence over the Dallol magmatic center is still present (Figure 2c) and a more complicated model of the magma chamber, such as a system of stacked sills [Field et al., 2012a] may better explain the local fringe pattern. However, the atmospheric noise affecting our interferogram and the lack of other interferograms spanning the 2004 intrusion do not allow us to constrain more complex magma chamber geometries. Other explanations of the discrepancy between the volumes of the dike and the Mogi source are the extremely fast rebound of the source regions [Nooner and Chadwick, 2009] or that volumetric changes of volatiles, in particular $\mathrm{CO}_{2}$, are expected to be more pronounced for shallow magma reservoirs. We calculated the 
Table 1. Comparison between Dallol and other dike intrusions occurred elsewhere along divergent plate boundaries. The ratio between the total seismic moment release and the total geodetic moment, SM/GM, represents the seismic component associated with the total displacement.

\begin{tabular}{|c|c|c|c|c|c|c|c|}
\hline Area & Data & MI & $\begin{array}{l}\text { Seism. Mom. } \\
\left(10^{17} \mathrm{Nm}\right)\end{array}$ & $\begin{array}{c}\text { Geod. Mom. } \\
\left(10^{17} \mathrm{Nm}\right)\end{array}$ & $\begin{array}{c}\text { SM/GM } \\
\%\end{array}$ & $\begin{array}{l}\text { Volume } \\
\left(\mathrm{km}^{3}\right)\end{array}$ & Ref. \\
\hline \multirow[t]{6}{*}{ Dallol } & Oct-Nov 2004 & $2.6-5.5$ & 2.28 & 22.0 & 10.4 & 0.058 & \\
\hline & Sep 2005 & $1.8-5.5$ & $25^{\mathrm{a}}-34^{\mathrm{b}}$ & $800^{\mathrm{c}}-896^{\mathrm{b}}$ & $3.1-3.8$ & $1.8^{\mathrm{b}}-2.5^{\mathrm{c}}$ & $a, b, c$ \\
\hline & Jun 2006 & $2.5-4.7$ & 1.80 & 54.4 & 3.3 & 0.120 & $\mathrm{~d}$ \\
\hline & Jul 2006 & $2-3$ & 0.02 & 32.4 & 0.1 & 0.042 & $\mathrm{~d}$ \\
\hline & Sep 2006 & $2.6-3.4$ & & 32.0 & $0.1^{\mathrm{a}}$ & 0.088 & $\mathrm{a}$ \\
\hline & Aug 2007 & $<3$ & 0.01 & 24.1 & 0.0 & 0.048 & $\mathrm{~d}$ \\
\hline \multirow[t]{6}{*}{ Dabbahu } & Nov 2007 & $2.9-4.5$ & 1.03 & 60.1 & 1.7 & 0.15 & $\mathrm{~d}$ \\
\hline & Mar-Apr 2008 & $<3$ & 0.16 & 37.2 & 0.4 & 0.088 & $\mathrm{~d}$ \\
\hline & Jul 2008 & $<3$ & 0.08 & 32.1 & 0.2 & 0.066 & $\mathrm{~d}$ \\
\hline & Oct 2008 & $1.8-4.6$ & 1.78 & 78.8 & 2.3 & 0.17 & $\mathrm{~d}$ \\
\hline & Feb 2009 & $2-3.5$ & 0.27 & 30.2 & 0.9 & 0.077 & $\mathrm{~d}$ \\
\hline & Jun 2009 & $<4$ & 0.01 & 18.1 & 0.1 & 0.046 & $\mathrm{~d}$ \\
\hline Lake Natron & Jul-Aug 2007 & $3-5.9$ & 14.00 & 40.0 & 35.0 & 0.09 & $\mathrm{e}$ \\
\hline Harrat Lunayyir & Apr-Jun 2009 & $3-5.4$ & 2.79 & 44.1 & 6.3 & 0.13 & $\mathrm{f}$ \\
\hline
\end{tabular}

${ }^{\mathrm{a}}$ Keir personal communication.

${ }^{\mathrm{b}}$ Wright et al. [2006].

${ }^{\mathrm{c}}$ Grandin et al. [2009].

${ }^{\mathrm{d}}$ Belachew et al. [2011].

${ }^{\mathrm{e}}$ Calais et al. [2008].

${ }^{\mathrm{f}}$ Pallister et al. [2010].

volume change of a magma chamber at $4 \mathrm{~km}$ depth, such as at Dabbahu, and $2.4 \mathrm{~km}$ depth, as in Dallol, using the formulations in Johnson et al. [2000]. We find that the volume change of a chamber at $2.4 \mathrm{~km}$ depth is $\sim 15 \%$ smaller than the volume change of a chamber at $4 \mathrm{~km}$ depth, assuming a relatively volatile-rich magma with a $\mathrm{CO}_{2}$ weight fraction of $0.0004 . \mathrm{CO}_{2}$ weight fraction values at Dabbahu are generally $\leq 0.0004$ and rarely as high as 0.0015 [Field et al., 2012a].

[18] The ratio between the seismic moment (SM) and geodetic moment (GM) for the 2004 Dallol dike intrusion was $10 \%$. The deformation seismically accommodated at Dallol was greater than during the 2005-2009 dike intrusions in the Dabbahu rift, when the SM/GM ratio varied between 1-4\% [Belachew et al., 2011; Grandin et al., 2009; Wright et al., 2006] (Table 1). A more similar SM/GM ratio, $\sim 6 \%$, was observed during the 2009 Harrat Lunayyir intrusion (Saudi Arabia) [Pallister et al., 2010] (Table 1), while during the 2007 intrusion in Lake Natron (Tanzania) up to $30 \%$ of the deformation was seismically accommodated [Calais et al., 2008] (Table 1). This suggests that faulting associated with dike emplacement may be more prominent where intrusion occurs near larger and longer faults along the margins of a rift valley. The deformation at Dallol shows that when the continent-to-ocean transition is confined to a narrow zone, dike induced slip of faults initiated during earlier phases of extension can contribute significantly to opening of the rift. This may be important to consider when reconstructing the evolution of ancient rifted volcanic continental margins, where the interaction between magma intrusion and faults is commonly ignored.

[19] Acknowledgments. We thank both anonymous reviewers for their very constructive comments. Our work is supported by the Natural Environment Research Council grants NE/D008611/1, NE/D01039X/1, NE/E007414/1 and a Royal Society University Research Fellowship to T. J. Wright. SAR data copyright ESA from CAT 1 3435. Partly founded with PRIN 2009 funds (2009H37M59, V. Acocella). We acknowledge the IRIS DMC for access to the seismic waveforms and also the ISC for their earthquake catalog.
[20] The Editor thanks Paul Lundgren and W. Buck for assisting in the evaluation of this paper.

\section{References}

Amelung, F., C. Oppenheimer, P. Segall, and H. Zebker (2000), Ground deformation near Gada 'Ale Volcano, Afar, observed by radar interferometry, Geophys. Res. Lett., 27(19), 3093-3096, doi:10.1029/2000GL008497.

Barberi, F., and J. Varet (1970), The Erta Ale volcanic range (Danakil depression, northern Afar, Ethiopia), Bull. Volcanol., 34(4), 848-917, doi:10.1007/BF02596805.

Belachew, M., C. Ebinger, D. Coté, D. Keir, J. V. Rowland, J. O. S. Hammond, and A. Ayele (2011), Comparison of dike intrusions in an incipient seafloor spreading segment in Afar, Ethiopia: Seismicity perspectives, J. Geophys. Res., 116, B06405, doi:10.1029/2010JB007908.

Beyene, A., and M. G. Abdelsalam (2005), Tectonics of the Afar depression: A review and synthesis, J. Afr. Earth Sci., 4l(1-2), 41-59, doi:10.1016/j.jafrearsci.2005.03.003.

Bonatti, E., C. Emiliani, G. Ostlund, and H. Rydell (1971), Final desiccation of the Afar Rift, Ethiopia, Science, 172(3982), 468-469, doi:10.1126/ science.172.3982.468.

Calais, E., et al. (2008), Strain accommodation by slow slip and dyking in a youthful continental rift, East Africa, Nature, 456(7223), 783-787, doi:10.1038/nature 07478

Carniel, R., J. E. Munoz, and J. Jones (2010), A geophysical multi-parametric analysis of hydrothermal activity at Dallol, Ethiopia, J. Afr. Earth Sci., 58, 812-819, doi:10.1016/j.jafrearsci.2010.02.005.

Cervelli, P., P. Segall, F. Amelung, H. Garbeil, C. Meertens, S. Owen, A. Miklius, and M. Lisowski (2002), The 12 September 1999 Upper East Rift Zone dike intrusion at Kilauea Volcano, Hawaii, J. Geophys. Res., 107(B7), 2150, doi:10.1029/2001JB000602.

Craig, T. J., J. A. Jackson, K. Priestley, and D. McKenzie (2011), Earthquake distribution patterns in Africa: Their relationship to variations in lithospheric and geological structure, and their rheological implications, Geophys. J. Int., 185, 403-434, doi:10.1111/j.1365-246X.2011.04950.x.

Einarsson, P., and B. Brandsdóttir (1980), Seismological evidence for lateral magma intrusion during the July 1978 deflation of the Krafla volcano in NE Iceland, J. Geophys., 47, 160-165.

Field, L., J. Blundy, R. A. Brooker, T. Wright, and G. Yirgu (2012a), Magma storage conditions beneath Dabbahu Volcano (Ethiopia) constrained by petrology, seismicity and satellite geodesy, Bull. Volcanol., 74, 981-1004, doi:10.1007/s00445-012-0580-6.

Field, L., T. Barnie, J. Blundy, R. A. Brooker, D. Keir, E. Lewi, and K. Saunders (2012b), Integrated field, satellite and petrological observations of the November 2012 eruption of Erta Ale, Bull. Volcanol., doi:10.1007/s00445-012-0660-7, in press. 
Ghebreab, W., and S. Solomon (1994), Formation of a recent asymmetric graben-in-graben structure at Bada, the Danakil depression of Eritrea, Geosci. Dev., 1, 16-18.

Grandin, R., et al. (2009), September 2005 Manda Hararo-Dabbahu rifting event, Afar (Ethiopia): Constraints provided by geodetic data, J. Geophys. Res., 114, B08404, doi:10.1029/2008JB005843.

Gudmundsson, A. (1995), Stress fields associated with oceanic transform faults, Earth Planet. Sci. Lett., 136(3-4), 603-614, doi:10.1016/0012821X(95)00164-8.

Hamling, I., A. Ayele, L. Bennati, E. Calais, C. J. Ebinger, D. Keir, E. Lewi, T. J. Wright, and G. Yirgu (2009), Geodetic observations of the ongoing Dabbahu rifting episode: New dyke intrusions in 2006 and 2007, Geophys. J. Int., 178, 989-1003, doi:10.1111/j.1365-246X.2009.04163.x.

Hayward, N. J., and C. J. Ebinger (1996), Variations in the along-axis segmentation of the Afar Rift System, Tectonics, 15, 244-257, doi:10.1029/ 95TC02292.

Johnson, D. J. (1992), Dynamics of magma storage in the summit reservoir of Kilauea Volcano, Hawaii, J. Geophys. Res., 97, 1807-1820, doi:10.1029/ 91JB02839.

Johnson, D. J., F. Sigmundsson, and P. T. Delaney (2000), Comment on "Volume of magma accumulation or withdrawal estimated from surface uplift or subsidence, with application to the 1960 collapse of Kilauea Volcano" by T. T. Delaney and D. F. McTigue, Bull. Volcanol., 61, 491-493, doi:10.1007/s004450050006.

Jónsson, S., H. Zebker, P. Segall, and F. Amelung (2002), Fault slip distribution of the $1999 M_{\mathrm{w}} 7.1$ Hector Mine, California, earthquake, estimated from satellite radar and GPS measurements, Bull. Seismol. Soc. Am., 92, 1377-1389, doi:10.1785/0120000922.

Keir, D., et al. (2009), Evidence for focused magmatic accretion at segment centers from lateral dike injections captured beneath the Red Sea rift in Afar, Geology, 37, 59-62, doi:10.1130/G25147A.1.

Makris, J., and A. Ginzburg (1987), The Afar Depression: Transition between continental rifting and sea-floor spreading, Tectonophysics, 141, 199-214, doi:10.1016/0040-1951(87)90186-7.

McClusky, S., et al. (2010), Kinematics of the southern Red Sea-Afar Triple Junction and implications for plate dynamics, Geophys. Res. Lett., 37, L05301, doi:10.1029/2009GL041127.

Nooner, S. L., and W. W. Chadwick (2009), Volcanic inflation measured in the caldera of Axial Seamount: Implications for magma supply and future eruptions, Geochem. Geophys. Geosyst., 10, Q02002, doi:10.1029/ $2008 \mathrm{GC} 002315$.

Ogubazghi, G., W. Ghebreab, and J. Havskov (2004), Some features of the 1993 Bada earthquake swarm of southeastern Eritrea, J. Afr. Earth Sci. 38(2), 135-143, doi:10.1016/j.jafrearsci.2003.12.002.

Pagli, C., T. J. Wright, C. J. Ebinger, S. Yun, J. R. Cann, T. Barnie, and A. Ayele (2012), Shallow axial magma chamber at the slow-spreading Erta Ale Ridge, Nat. Geosci., 5, 284-288, doi:10.1038/ngeo1414.

Pallister, J. S., W. A. McCauslan, and S. Jonsson (2010), Broad accommodation of rift-related extension recorded by dyke intrusion in Saudi Arabia, Nat. Geosci., 3, 705-712, doi:10.1038/ngeo966.

Rivalta, E. (2010), Evidence that coupling to magma chambers controls the volume history and velocity of laterally propagating intrusions, J. Geophys. Res., 115, B07203, doi:10.1029/2009JB006922.

Rivalta, E., and P. Segall (2008), Magma compressibility and the missing source for some dike intrusions, Geophys. Res. Lett., 35, L04306, doi:10.1029/2007GL032521.

Roman, D. C., and K. V. Cashman (2006), The origin of volcano tectonic earthquake swarms, Geology, 34, 457-460, doi:10.1130/G22269.1.

Rosen, P. A., S. Henley, G. Peltzer, and M. Simons (2004), Updated repeat orbit interferometry package released, Eos Trans. $A G U, 85(5), 47$ doi:10.1029/2004EO050004

Siebert, L., T. Simkin, and P. Kimberly (2010), Volcanoes of the World, 3rd ed., 568 pp., Univ. of Calif. Press, Berkeley.

Wolfenden, E., C. Ebinger, G. Yirgu, A. Deino, and D. Ayelew (2004), Evolution of the northern Main Ethiopian rift: Birth of a triple junction, Earth Planet. Sci. Lett., 224, 213-228, doi:10.1016/j.eps1.2004.04.022.

Wright, T. J., Z. Lu, and C. Wicks (2003), Source model for the $M w 6.7$, 23 October 2002, Nenana Mountain earthquake (Alaska) from InSAR, Geophys. Res. Lett., 30(18), 1974, doi:10.1029/2003GL018014.

Wright, T. J., C. Ebinger, J. Biggs, A. Ayele, G. Yirgu, D. Keir, and A. Stork (2006), Magma maintained rift segmentation at continental rupture in the 2005 Afar dyking episode, Nature, 442, 291-294, doi:10.1038/ nature 04978 .

Wright, T. J., et al. (2012), Geophysical constraints on the dynamics of sreading centres from rifting episodes on land, Nat. Geosci., 5, 242-250, doi:10.1038/ngeo1428. 